\title{
The Effect of Pentobarbital Sodium on Growth Hormone Release in Shiba Goats
}

\author{
Etsuko KASUYA, Tsutomu HASHIZUME \\ and Shigeto KANEMATSU
}

Faculty of Agriculture, Iwate University, Morioka-shi 020

(Received May 18, 1995)

\begin{abstract}
The effect of intravenous (iv) injection of pentobarbital sodium (PB) on plasma concentration of growth hormone $(\mathrm{GH})$ in the Japanese Shiba goats was studied. 'An acute significant increase in plasma $\mathrm{GH}$ was observed in the goats after a single $\mathrm{PB}$ injection of $19 \mathrm{mg} /$ $\mathrm{kg} \mathrm{BW}$. Plasma GH concentration remained unchanged after injection of vehicle or $10 \mathrm{mg} / \mathrm{kg}$ $\mathrm{BW}$ PB in the goats. The present results suggested that anesthetic dose of PB induced a release of GH in the Shiba goats.
\end{abstract}

Anim. Sci. Technol. (Jpn.) $66(10): 854-856,1995$

Key words : pentobarbital sodium, growth hormone, Shiba goat

Growth hormone (GH) secretion is mainly regulated by two hypothalamic factors, growth hormone-releasing hormone and somatostatin (SRIF). Recently, it has been suggested that the other factors such as neurotransmitters may be involved in regulation of $\mathrm{GH}^{5}$.

Pentobarbital sodium (PB) stimulates GH release in rats ${ }^{3.7 .9,12)}$. However, it is possible that there are species differences in this phenomenon since the effect of $\mathrm{PB}$ on $\mathrm{GH}$ release has not been observed in $\operatorname{dogs}^{10)}$. Although it has been suggested that hypothalamic factors may play a major role in this phenomenon ${ }^{11)}$, the mechanism remains to be clarified. Moreover, the effect of $\mathrm{PB}$ on $\mathrm{GH}$ secretion in ruminant animals has never been reported. In the present study, the effect of PB on GH secretion was investigated in order to clarify the central nervous control of GH secretion in Japanesc Shiba goats.

\section{Materials and Methods}

Five female Shiba goats weighing $12.8 \pm 1.7$ $\mathrm{kg}$ in $\mathrm{BW}$ were used in the following experiments : two doses of pentobarbital sodium (PB, Somnopentyl, Pitman-Moore, Mundelein, IL, 10 $\mathrm{mg} / \mathrm{kg} \mathrm{BW}$ or $19 \mathrm{mg} / \mathrm{kg} \mathrm{BW}$ ) or $10 \%$ ethanol in physiological saline (vehicle of Somnopentyl, $0.6 \mathrm{ml} / \mathrm{kg}$ BW as control) were administered intravenously by a single injection. Since 19 $\mathrm{mg} / \mathrm{kg} \mathrm{BW}$ of $\mathrm{PB}$ had induced a significant increase in GH concentration in Shiba goats during brain surgery (unpublished data in our laboratory), we determined to use the same dose and its half dose in this experiment.

シバヤギの成長ホルモン放出に及ぼすベントバルビタールの效果：粕谷悦子・橋爪 力・兼松重任（岩手大学農学 部, 盛阔市 020) 
Before injections of PB or saline, animals were normal and standing. However, they fell and began to sleep just after injections of both doses of PB.

Blood samples were taken from animals through an indwelling catheter previously inserted into the external jugular vein by venipuncture. Blood was collected at $10-\mathrm{min}$ intervals for $1.5 \mathrm{~h}$ before and for $2.5 \mathrm{~h}$ after the drug injection. The blood samples were taken into heparinized tubes, and plasma was immediately separated by centrifugation (2,500 r.p. $\mathrm{m} ., 5 \mathrm{~min})$. The plasma was stored at $-20^{\circ} \mathrm{C}$ until GH assay.

GH concentrations were determined in $100 \mu l$ aliquots of plasma by a double-antibody radioimmunoassay ${ }^{8)}$. The GH standard preparation used and hormone for iodination were bGH-B1. The parallelism between caprine plasma $\mathrm{GH}$ and $\mathrm{bGH}$ was described previously ${ }^{6)}$. All samples were assayed in a single assay. The least detectable value of assay was $0.3 \mathrm{ng} / \mathrm{ml}$. The intra-assay coefficients of variation in this assay was $4.0 \%$.

Data were represented as mean $\pm \mathrm{SE}$. Statistical significance of differences were determined by Student's t-test or Cochran-Cox test after analysis of uniformity of variance by Bartlett's test ${ }^{14)}$.

\section{Results and Discussion}

Injections of a vehicle placebo failed to induce any significant change in plasma GH levels in female Shiba goats as shown in Fig. 1 $-\mathrm{A}$. When the $10 \mathrm{mg} / \mathrm{kg} \mathrm{BW}$ of $\mathrm{PB}$ was injected, plasma GH level tended to increase but not significantly 20 to $40 \mathrm{~min}$ after the injection compared with the preinjection values (Fig. 1B). However, injection of $19 \mathrm{mg} / \mathrm{kg} \mathrm{BW}$ of $\mathrm{PB}$ induced a significant five-fold increase in $\mathrm{GH}$ concentration $(\mathrm{P}<0.05) 30 \mathrm{~min}$ after the injection compared with the preinjection values (Fig.1-C). The elevated GH level declined within $30 \mathrm{~min}$ after the peak and returned to the preinjection level $2 \mathrm{~h}$ after the injection.
Both doses of PB injection induced deep anesthesia. The duration of deep sleep were $8-50$
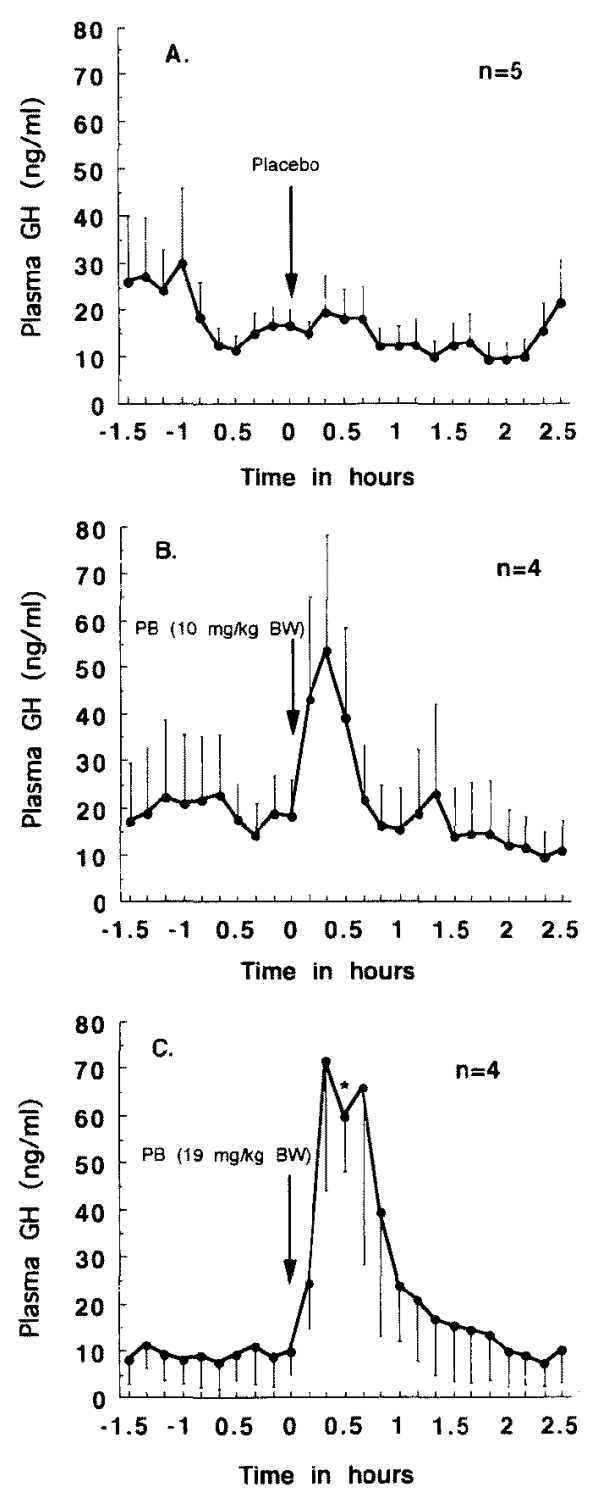

Fig. 1. The mean plasma $\mathrm{GH}$ level after iv injection of vehicle (A) or $10 \mathrm{mg} / \mathrm{kg} \mathrm{BW}$ of pentobarbital sodium (B) and $19 \mathrm{mg} / \mathrm{kg} \mathrm{BW}$ of $\mathrm{PB}$ (C). Arrows indicate time of injection. The mean $\mathrm{GH}$ concentration of 10 fractions before the injection was taken as a preinjection level. An asterisk indicates the statistical significance; ${ }^{*} \mathrm{P}<0.05$ as compared with the preinjection level. Each value represents the mean $\pm \mathrm{SE}$. 
and $25-120 \mathrm{~min}$ after the administration of 10 and $19 \mathrm{mg} / \mathrm{kg} \mathrm{BW}$ of $\mathrm{PB}$, respectively.

The present study clearly demonstrated that anesthetic dose of PB induced a remarkable GH release in goats. Unlike that of the $\operatorname{dog}^{10)}$, our result that $\mathrm{PB}$ induced $\mathrm{GH}$ release in Shiba goats was consistent with those reported in $\operatorname{rats}^{3,7,9,12)}$. In rats, since the $\mathrm{GH}$ releasing effect of $\mathrm{PB}$ was blocked by lesion of the hypothalamic ventromedial nucleus or isolation of mediobasal hypothalamus ${ }^{11}$, and since pentobarbital failed to stimulate $\mathrm{GH}$ release from dispersed and cultured rat anterior pituitary cells in vitro ${ }^{2)}$, it has been suggested that the drug exerted an effect via the central nervous system. It has been reported that PB decreased SRIF release in rat hypophysial portal blood ${ }^{4)}$ or brain ${ }^{13)}$. Furthermore, SRIF blocked PB-stimulated GH release in rats ${ }^{1)}$. However, there was also a possibility that $\mathrm{GH}^{-}$ releasing hormone might be involved in $\mathrm{PB}-$ induced $\mathrm{GH}$ stimulation in rats because $\mathrm{PB}$ induced $\mathrm{GH}$ release was blocked by the destruction of the arcuate nucleus. In coclusion, the present results suggested that anesthetic dose of $\mathrm{PB}$ induced a significant $\mathrm{GH}$ release in goats.

\section{Acknowledgements}

The authors wish to thank to Dr. Tetsu Johke, National Institute of Animal Industry, Japan for providing antiserum to $\mathrm{bGH}$ and Professor Katsumi Wakabayashi, the Institute of Endocrinology, Gunma University, Japan for providing goat anti-monkey IgG serum to $\mathrm{bGH}$ and monkey serum. The authors are also indebted to NIDDK and National Hormone and Pituitary Program, USA for providing bGH (USDA bGH-B1) for standard preparation and iodination. Finally, we would like to thank Dr. Paul Langman, Iwate Medical University for assistance with English usage.

\section{References}

1) Brazeau P, Rivier J, Vale W, Guillemin R. Inhi- bition of growth hormone secretion in the rat by synthetic somatostatin. Endocrinology, 94 : 184-187. 1974.

2) Brown M, Vale W. Growth hormone release in the rat:effects of somatostatin and thyrotropin-releasing factor. Endocrinology, 97: 1151-1156. 1975.

3) Chihara K, Arimura A, Chihara M, Schally AV. Effect of intraventricular administration of anti-somatostatin gamma-globulin on the lethal dose- -50 of strychnine and pentobarbital in rats. Endocrinology, $103: 912-916.1978$.

4) Chihara K, Arimura A, Schally AV. Immunoreactive somatostatin in rat hypophyseal portal blood: effects of anesthetics. Endocrinology, 104 : 1434-1441. 1979.

5) Devesa J, Lima L, Tresguerres JAF. Neuroendocrine control of growth hormone secretion in humans. Trends Endocrinol. Metab., 3: 175-183. 1992.

6) Hashizume $T$, Kanematsu $S$. Effects of cholecystokinin octapeptide on the release of growth hormone in perifused pituitary and hypothalamus of the goat. Anim. Sci. Technol. (Jpn.), 62 : 343-350. 1991.

7) Howard N, Martin JM. A stimulatory test for grow th hormone release in the rat. Endocrinology, $88: 497-499.1971$.

8) Johke T. Effect of TRH on circulating growth hormone, prolactin and triiodothyronine levels in the bovine. Endocrinol. Japon, $25: 19$ 26. 1978.

9) Kokka N, Garcia JF, George R, Elliott HW. Growth hormone and ACTH secretion: evjdence for an inverse relationship in rats. Endocrinology, 90:735-743. 1972.

10) Lovinger RD, Connors $\mathrm{MH}$, Kaplan SL, Ganong WF, Grumbach MM. Effect of Ldihydroxyphenylalanine (L-dopa), anesthesia and surgical stress on the secretion of growth hormone in the dog. Endocrinology, $95: 1317-$ 1321. 1974.

11) Martin JB. Studies on the mechanism of pentobarbital-induced $\mathrm{GH}$ release in the rat. Neuroendocrinology, 13 : 339-350. 1974.

12) Settembrini BP, Gallardo MGP, Tramezzaini $\mathrm{JH}$. Pituitary graft inhibits the release of prolactin and growth hormone induced by sodium pentobarbital. Med. Sci. Res., 16 : 765766. 1988.

13) Takahashi $H$, Shintani $Y$, Okauchi $T$, Ishikawa M, Bando H, Azekawa T, Morita Y, Saito S. Measurement of somatostatin release in rat brain by microdialysis. J. Neurosci. Methods, 52 : 33-38. 1994.

14) Wakabayashi $K$. Arrangement of experimental data. 44-57, 90-133. Baihukan. Tokyo. 1984. 